\title{
AKTIVITAS DIURESIS Leucaena leucocephala.L PADA MENCIT JANTAN (Mus musculus)
}

\author{
Muhammad Ricky Ramadhian ${ }^{1 *}$,Khairil Pahmi ${ }^{2}$, Muhammad Taupik $^{3}$ \\ ${ }^{1}$ Departemen Mikrobiologi dan Parasitologi, Fakultas Kedokteran, Universitas Lampung, \\ Jl. Prof. Dr. Ir. Sumantri Brojonegoro, RW.No: 1, Gedong Meneng, Kec. Rajabasa, Kota Bandar \\ Lampung, Lampung \\ 2 Program Studi DIII Farmasi, Fakultas Ilmu Kesehatan, Universitas Nahdlatul Wathan Mataram, \\ Jl. Merdeka Raya, Karang Pule, Mataram \\ 3 Jurusan Farmasi, Fakultas Olahraga dan Kesehatan, Universitas Negeri Gorontalo, \\ Jl. Jenderal Sudirman No. 06 Kota Gorontalo 96128, Indonesia \\ *Penulis Korespondensi. Email: mricky.ramadhian@fk.unila.ac.id
}

\begin{abstract}
ABSTRAK
Diuretik adalah senyawa atau obat yang dapat meningkatkan volume urin [11]. Penelitian ini bertujuan untuk mengetahui aktivitas ekstrak etanol daun lamtoro (Leucaena leucocephala L.) sebagai diuretik pada mencit jantan dan juga untuk mengetahui konsentrasi optimal ekstrak daun lamtoro sebagai diuretik pada mencit jantan. Metode yang digunakan adalah mengamati aktivitas fisik urin yang dihasilkan selama 120 menit. Ekstraksi daun lamtoro dilakukan dengan cara maserasi mennggunakan pelarut etanol, kemudian dilakukan uji skrining fitokimia. Hasil skrining menyatakan positif menggandung alkaloid, flavonoid, terpenoid, dan tannin. Hewan uji yang digukanan sebanyak 25 ekor mencit, dibagi dalam 5 kelompok. Kelompok 1 diberi suspensi Na-CMC 1\% b/v, kelompok 2 diberi suspensi furosemid 0,0041 \% $\mathrm{b} / \mathrm{v}$, kelompok 3 diberi ekstrak etanol daun lamtoro $25 \% \mathrm{~b} / \mathrm{v}$, kelompok 4 diberi ekstrak etanol daun lamtoro $50 \%$ b/v, dan kelompok 5 diberi ekstrak etanol daun lamtoro $75 \%$ b/v. Diukur volume urin mencit pada menit ke- 15, 30, 45, 60, 75, 90, 105, dan 120. Data dianalisis dengan uji statistik ANOVA $(p<0,01)$ untuk melihat pengaruh variasi ekstrak terhadap volume urin yang dihasilkan. Hasil penelitian menunjukan adanya pengaruh ekstrak yang diberikan terhadap volume urin yang dihasilkan yang berarti daun lamtoro memiliki aktivitas sebagai diuretik.
\end{abstract}

Kata Kunci:

Diuretik; Leucaena leucocephala L.; Volume Urin

$\begin{array}{lcc}\text { Diterima: } & \text { Disetujui: } & \text { Online: } \\ 8-02-2021 & 20-02-2021 & 5-03-2021\end{array}$

ABSTRACT

Diuretics are compounds or drugs that can increase urine volume (Sunaryo, 1995). This study focused on exploring the activity and concentration of ethanol extract of lamtoro leaves (Leucaenaleucocephala L.) as a diuretic in male house mice (Musmusculus) using experimental research. The method used was to observe the physical activity of urine produced for 120 minutes. Lamtoro leaves extraction was done by maceration using solvent ethanol, then phytochemical screening tests. The screening results stated positively contained alkaloids, flavonoids, terpenoids, and tannins. The animals used were 25 house mice, divided into 5 groups. Group 1 was given Na-CMC $1 \% \mathrm{w} / \mathrm{v}$ suspension, group 2 with furosemide suspension $0.0041 \% \mathrm{w} / \mathrm{v}$, group 3 with $25 \% \mathrm{w} / \mathrm{v}$ lamtoro leaf ethanol extract, group 4 , ethanol extract $50 \%$ $\mathrm{w} / \mathrm{v}$ lamtoro leaf, and group $5 \mathrm{was}$ ethanol extract $75 \% \mathrm{w} / \mathrm{v}$ of lamtoro leaves. Urine volume of the house mice was measured at $15,30,45,60,75,90,105$, and 120 minutes. Data were 
analyzed by ANOVA statistical test $(\mathrm{p}<0.01)$ to determine the effect of variations of extract on the volume of urine produced. The results revealed the effect of the extract given on the volume of urine produced; meaning that lamtoro leaves had diuretic activity.

\begin{tabular}{ccc}
\multicolumn{3}{c}{ Copyright $\odot$ 2021Jsscr. All rights reserved. } \\
\hline Keywords: Diuretics; Leucaenaleucocephala L.; Urine Volume \\
\hline Received: & Accepted: & Online: \\
2021-02-8 & $2021-02-20$ & $2021-03-5$ \\
\hline
\end{tabular}

\section{Pendahuluan}

Setiap mahluk hidup terdiri dari beberapa komponen-komponen penyusun. Diantaranya air yang digunakan sebagai pelarut dan juga zat terlarut yaitu elektrolit dan non elektrolit. Enam puluh persen berat tubuh manusia tersusun atas air dimana menempati cairan intrasel dan ekstrasel. Elektrolit merupakan zat bermuatan terdiri dari kation anion, untuk non elektrolit adalah substansi seperti urea dan glukosa dimana memiliki berat molekul lebih besar jika dibandingkan dengan zat - zat elektrolit [9].

Tubuh setiap harinya perlu melakukan keseimbangan penyusun zat elektrolit seperti air, dan asam basa. Asupan dan pengeluaran air atau elektrolit diatur lewat hubungan timbal balik antara hormon dan saraf yang mengatur perilaku dan kebiasaan makan [2]. Upaya mempertahankan keseimbangan yang tepat antara asupan dan keluarnya air atau elektrolit amat sangatlah penting. Jika tubuh mengalami kelebihan cairan ekstrasel, penumpukan cairan di dalam tubuh atau biasa dikenal dengan udem akan terjadi. Salah satu obat yang dapat digunakan untuk mengeluarkan cairan-cairan ekstrasel yang berlebihan didalam tubuh adalah golongan diuretik [8].

Diuretik merupakan obat yang dapat digunakan untuk mengeluarkan cairan berlebihan didalam tubuh dengan memicu proses pembentukan urin. Diuretik dapat bekerja dengan meningkatkan eksresi air, natrium dan klorida sehingga mampu menyeimbangkan cairan ekstrasel dan menurunkan volume darah dalam tubuh. Selain itu diuretik memiliki fungsi utama dalam memobilisasi cairan udem yang berarti dapat mengubah keseimbangan cairan dalam tubuh, sehingganya kapasitas cairan ekstral sel dapat kembali normal. Salah satu obat golongan diuretik yang sering digunakan adalah furosemide [8].

Furosemid adalah golongan yang bekerja pada lengkung Henle bagian menaik dan merupakan obat diuretik kuat. Furosemid dapat bekerja pada pasien dengan penyakit paru akut dan juga efektif pada kondisi udem. Furosemid dapat bekerja secara pesat, seperti pemberian secara oral dalam 0,5-1 jam dan bertahan selama 4-6 jam, sedangkan untuk intravena selama 2,5 jam. Masa kerja furosemide selama 2-3 jam, untuk waktu paruhnya sangat bergantung pada fungsi dari organ berupa ginjal. Agen ansa disini bekerja pada bagian sisi luminal tubulus. Sehingganya respon diuretik yang dihasilkan berkaitan dengan ekresi urin. Sebagai efek diuretik, pada bagian agen ansa memiliki efek yang dapat bekerja secara langsung di dalam peredaran darah melalui tatanan beberapa pembuluh darah. Selain obat-obat sintesis, penggunaan tanaman juga telah dilaporkan dapat digunakan dalam pengobatan secara tradisional [6].

Penggunaan tanaman yang dijadikan sebagai obat tradisional dalam penyembuhan penyakit juga biasa dilakukan oleh masyarakat Indonesia dan masih dipercayai kemanjurannya. Indonesia dikenal sebagai salah satu negara tropis yang memiliki 
sumber tanaman obat yang berlimbah. Pemanfaatan tanaman sebagai obat sudah dikenal sejak lama oleh masyarakat di Indonesia maupun di Negara lain. Bahan kimia yang terkandug dalam tanaman memiliki banyak manfaat termasuk untuk bahan pembuatan obat berbagai jenis penyakit secara tradisional. Salah satu tanaman yang biasa digunakan sebagai obat adalah lamtoro. Tanaman lamtoro (Leucaena leucochepala L.) termasuk leguminoseae yang tergolong dalam subfamili mimosaceae, banyak mengandung bahan aktif obat-obatan berupa : Alkaloid, Saponin, Flavonoid, Tanin, Mimosin, Leukanin, Protein, Asam lemak dan Serat. Penggunaan lamtoro dalam pengobatan tradisional lebih aman. Dimana lamtoro dipercayai memiliki efek samping yang kecil bila digunakan dengan benar dan tepat, dan juga lebih murah karena biasanya tanaman yang digunakan mudah didapatkan dan banyak tumbuh liar di alam [4].

Bahwa lamtoro selain digunakan sebagai pakan hewan ternak juga dapat digunakan dalam pengobatan tradisional pada penyakit rematik, penurunan tekanan darah tinggi, dan pereda nyeri pada perut. Pengujian aktivitas diuretik ini dilandaskan dengan adanya kepercayaan bahwa daun lamtoro dapat digunakan sebagai penurun tekanan darah yang bekerja dengan cara meluruhkan air seni (diuresis).

Dari uraian diatas dan beberapa hasil dari penelitian yang telah dilakukan, maka peneliti mengambil sampel daun lamtoro karena populasinya sangat banyak juga mudah ditemukan dan masih sangat dipercayai oleh masyarakat sekitar dalam pengobatan tradisional.

\section{Metode}

Penelitian yang akan dilakukan merupakan eksperimental laboratorium yang diharapkan dapat melihat apakah pemberian ekstrak etanol daun lamtoro (Leucaena leucocephala L.) yang diujikan pada mencit jantan (Mus musculus) dapat memberikan aktivitas diuretik. Adapun metode yang dilakukan adalah skrining fitokimia, pengamatan sifat fisik urin, perhitungan aktivitas diuretik, dan analisis data menggunakan One Way ANOVA.

\subsection{Alat dan Bahan}

Alat yang digunakan bejana Maserasi (Pyrex), batang pengaduk, blender, disposible syringe 1, 3, dan $5 \mathrm{ml}$, evaporator, gelas kimia (Pyrex), gelas ukur (Pyrex), kandang hewan, lumpang, NGT (Nasogastric Tube) no. 3,5, sudip, sarung tangan, tempat minum hewan uji, timbangan analitik (Precisa), timbangan hewan (Ohaus), wadah penampung urin modifikasi. Bahan yang digunakan Aquades, etanol $96 \%$, furosemide tablet, sampel daun lamtoro (Leucaena leucocephala L.), natrium karbosil metil selulosa (Na-CMC), dan mencit jantan (mus musculus).

\subsection{Prosedur Penelitian}

\section{a. Sampel Penelitian}

Sampel daun lamtoro (Leucaena leucocephala L.) dipanen pada pagi hari saat tumbuhan masih segar, kemudian dilakukan sortasi basah dan pencucian menggunakan air mengalir untuk menghilangkan kotoran-kotoran yang masih menempel pada daun bandotan, kemudian sampel dikeringkan tetapi tidak terpapar langsung oleh sinar matahari. Selanjutnya dilakukan sortasi kering untuk memisahkan dari daun yang rusak selama pengeringan. Langkah terakhir yaitu daun bandotan yang telah disortasi kering kemudian dibuat dalam bentuk serbuk. 


\section{b. Pembuatan Ekstrak}

Simplisia daun bandotan dilakukan dengan cara maserasi. Bahan yang telah kering kemudian dihaluskan menggunakan blender hingga berbentuk serbuk. Simplisia ekstrak daun lamtoro (Leucaena leucocephala L.) yang telah dihaluskan, ditimbang 500 gram kemudian diekstraksi menggunakan etanol 96\%. Serbuk simplisia daun bandotan sebanyak 500 gram dimasukkan kedalam toples kaca kemudian direndam dengan pelarut etanol $96 \%$ ditutup menggunakan aluminium foil dan dibiarkan selama lima hari sambil sesekali diaduk. Setelah lima hari, sampel yang direndam tersebut disaring dengan menggunakan kertas saring sehingga menghasilkan filtrat kemudian dipekatkan dengan menggunakan rotary vacuum evaporator hingga diperoleh ekstrak kental dan dihitung persen rendamennya.

\section{c. Uji Skrining Fitokimia}

a. Uji alkaloid

Ekstrak dilarutkan dengan $5 \mathrm{~mL}$ HCL larutan yang didapat kemudian dimasukkan dalam tabung reaksi. Tabung ditambahkan pereaksi Dragendroff sebanyak 3 tetes. Terbentuknya endapan jingga pada tabung menunjukkan adanya alkaloid [16].

b. Uji flavonoid

Ekstrak kemudian ditambahkan etanol. Kedalam larutan ditambahkan serbuk magnesium dan ditambahkan HCL. Terbentuk larutan berwarna merah jingga menunjukkan adanya flavonoid.

c. Uji terpenoid

Uji terpenoid dilakukan dengan reaksi Lieberman - Burchard. Terbentuknya larutan hijau biru menunjukkan adanya terpenoid [17].

d. Uji saponin

Ekstrak ditambahkan dengan $10 \mathrm{~mL}$ air panas kemudian didinginkan, dikocok kuat selama 10 detik. Terbentuk buih yang mantap selama tidak kurang 10 menit.

e. Uji tannin

Ekstrak ditambahkan dengan $1 \mathrm{~mL}$ larutan Fe (III) klorida 1\%. Jika terbentuk warna biru tua, biru kehitaman atau hitam kehijauan menunjukkan adanya senyawa tannin [17].

d. Uji Aktivtas Diuresis

Mencit yang telah diadaptasikan dibagi menjadi 5 kelompok dimana masing-masing kelompok terdiri dari 5 ekor mencit lalu diukur terlebih dahulu volume urin normal. Volume urin dikumpulkan setiap 15, 30, 45, 60, 75, 90, 105, dan 120 menit. Setelah didapatkan urin mencit normal, maka diberikan perlakuan sebagai berikut: Kelompok 1 (suspensi Na-CMC 1\% b/v), Kelompok 2 (suspensi Furosemid 0,0041\% b/v), kelompok 3 (suspensi ekstrak etanol daun Lamtoro 25\% b/v), kelompok 4 (suspensi ekstrak etanol daun Lamtoro $50 \%$ b/v), dan kelompok 5 (suspensi ekstrak etanol daun Lamtoro $75 \%$ b/v) dan diamati selama 120 menit setiap 15 menit.

3. Hasil dan Pembahasan

3.1 Ekstaksi dan Skrining Fitokimia

Hasil ekstraksi daun lamtoro (Leucaena leucocephala L.) menunjukan persen rendamen yang dihasilkan dari proses ekstraksi sampel daun lamtoro (Leucaena leucochepala L.) adalah sebesar $11,7 \%$. Presentase ini menunjukan bahwa proses penyarian berlangsung baik, presentase rendamen dapat dikatakan sempurna jika hasilnya berkisar antara 10$15 \%$ [10]. Berikut hasil rendamen ditampilkan pada tabel 1. 
Tabel 1. Hasil rendamen ekstrak daun lamtoro (Leucaena leucochepala L.)

\begin{tabular}{cccc}
\hline Berat Sampel (gr) & Pelarut $(\mathrm{mL})$ & Berat Ekstrak $(\mathrm{gr})$ & Rendamen \\
\hline $\mathbf{2 0 0}$ & 3000 & 23.4 & $11,7 \%$ \\
\hline
\end{tabular}

Selanjutnya hasil skrining fitokimia menunjukan sampel daun lamtoro (Leucaena leucochepala L.) positif mengandung senyawa alkaloid, flavonoid, terpenoid, dan tannin. Lamtoro (Leucaena leucochepala L.) menggandung zat aktif berupa alkaloid, flavonoid, dan tannin. Hasil pengujian fitokimia bisa dilihat pada tabel 2.

Tabel 2. Hasil skrining fitokimia

\begin{tabular}{cccc}
\hline Senyawa & Pereaksi & Hasil Uji & Keterangan \\
\hline Alkaloid & $\mathrm{HCl} 2 \mathrm{~N}+$ Pereaksi Mayer & Merah Keruh & $\begin{array}{c}\text { Positif } \\
(+)\end{array}$ \\
\hline Flavonoid & $\mathrm{Mg}+\mathrm{HCl} \mathrm{Pekat}$ & Merah & $\begin{array}{c}\text { Positif } \\
(+)\end{array}$ \\
\hline Saponin & Aquadest & Tidak berbusa & $\begin{array}{c}\text { Negatif } \\
(-)\end{array}$ \\
\hline Steroid & Kloroform $+\mathrm{H}_{2} \mathrm{SO}_{4}$ & Hijau Kehitaman & $\begin{array}{c}\text { Negatif } \\
(-)\end{array}$ \\
\hline Terpenoid & Kloroform $+\mathrm{H}_{2} \mathrm{SO}_{4}$ & Hijau Kehitaman & $\begin{array}{c}\text { Positif } \\
(+)\end{array}$ \\
\hline Tannin & $\mathrm{FeCl}_{3}$ & Hijau Kehitaman & $\begin{array}{c}\text { Positif } \\
(+)\end{array}$ \\
\hline
\end{tabular}

Pada pengujian alkaloid akan terjadi reaksi pengendapan karena adanya penggantian ligan. Hal ini mengakibatkan terbentuknya endapan jingga pada penambahan pereaksi Dragendorff karena nitrogen digunakan untuk membentuk ikatan kovalen koordinat dengan $\mathrm{K}^{+}$yang merupakan ion logam. Pengujian terpenoid didasarkan pada kemampuan senyawa untuk membentuk warna dengan $\mathrm{H}_{2} \mathrm{SO}$ pekat dalam pelarut asam asetat anhidrat. Uji terpenoid ekstrak daun lamtoro (Leucaena leucochepala L.) menghasilkan perubahan warna hijau kehitaman yang menunjukkan positif mengandung terpenoid [4].

Pada uji flavonoid daun lamtoro (Leucaena leucochepala L.) ditambahkan magnesium dan $\mathrm{HCl}$ menunjukkan terbentuknya warna merah sehingga dikatakan positif mengandung flavonoid. Magnesium dan $\mathrm{HCl}$ pekat pada uji ini berfungsi untuk mereduksi inti benzopiron yang terdapat pada struktur flavonoid sehingga terbentuk perubahan warna menjadi merah atau jingga [18]. Daun lamtoro (Leucaena leucochepala L.) mengandung senyawa tannin karena pada saat di tambahkan pereaksi terbentuk warna hijau kehitaman. Perubahan warna ini terjadi ketika penambahan $\mathrm{FeCl}_{3}$ yang bereaksi dengan salah satu gugus hidroksil yang ada pada senyawa tannin[18].

\subsection{Pengkuran Aktivitas Diuresis}

Hasil pengukuran volume urin menunjukan hasil bahwa pemberian ketiga variasi ekstrak menghasilkan urin masing-masing sebesar $2 \mathrm{~mL}, 5.4 \mathrm{~mL}$ dan $6.5 \mathrm{~mL}$, sedangkan untuk pemberian suspensi furosemid sebanyak $7 \mathrm{~mL}$. Dari hasil diatas, pemberian ekstrak daun lamtoro juga dapat digunakan sebagai diuretik yang ditunjukan dengan adanya peningkatan volume urin. Untuk kontrol negatif pemberian suspensi Na-CMC hanya menghasilkan urin sebanyak $0.1 \mathrm{~mL}$. Masing-masing hasil urin tersebut didapatkan selama 120 menit setelah perlakuan. 
Hasil pengamatan warna urin menunjukan warna urin yang dihasilkan masing-masing kelompok bervariasi. Untuk kelompok 1 menghasilkan warna kuning, kelompok 2 berwarna kuning muda, kelompok 3 warna kuning, kelompok 4 berwarna kuning muda, sedangkan untuk kelompok 5 berwarna kuning pucat, bahwa untuk urin normal dapat dilihat dari warna yang dihasilkan berupa tidak berwarna, kuning muda, kuning, dan kuning tua [12]. Hasil pengukuran volume urin dan pengamatan warna urin ditampilkan pada tabel 3 dan atbel 4 .

Tabel 3. Hasil pengukuran volume urin

\begin{tabular}{|c|c|c|c|c|c|c|c|c|c|c|}
\hline \multirow[t]{2}{*}{ Kelompok } & \multicolumn{8}{|c|}{$\begin{array}{c}\text { Volume Urin }(\mathrm{mL}) \\
/ 120 \text { Menit Setelah Pemberian }\end{array}$} & \multirow[t]{2}{*}{$\begin{array}{c}\Sigma \\
(\mathrm{mL})\end{array}$} & \multirow[t]{2}{*}{$\begin{array}{c}\bar{X} \pm \mathrm{SD} \\
(\mathrm{mL})\end{array}$} \\
\hline & 15 & 30 & 45 & 60 & 75 & 90 & 105 & 120 & & \\
\hline 1 & 0.1 & 0.4 & 0.1 & 0.3 & 0.1 & 0.0 & 0.0 & 0.0 & 1 & $0.13 \pm 0.15$ \\
\hline 2 & 0.6 & $\overline{0.7}$ & 1.0 & 1.2 & 1.2 & 1.0 & 0.8 & 0.5 & 7 & $0.88 \pm 0.27$ \\
\hline 3 & 0.1 & 0.0 & 0.5 & 0.7 & 0.5 & 0.2 & 0.0 & 0.0 & 2 & $0.25 \pm 0.28$ \\
\hline 4 & 0.4 & 0.6 & 1.0 & 1.0 & 1.0 & 0.7 & 0.5 & 0.2 & 5.4 & $0.68 \pm 0.31$ \\
\hline 5 & 0.6 & $\overline{0.8}$ & 1.2 & 1.3 & 1.1 & 0.8 & 0.6 & 0.1 & 6.5 & $0.81 \pm 0.41$ \\
\hline
\end{tabular}

Keterangan :

Kelompok 1

Kelompok 2

Kelompok 3

: Diberikan suspensi Na-CMC $1 \% \mathrm{~b} / \mathrm{v}$.

Kelompok 4 : Diberikan ekstrak etanol daun lamtoro $50 \%$ b/v.

Kelompok 5 : Diberikan ekstrak etanol daun lamtoro $75 \%$ b/v.

$\Sigma \quad$ : Jumlah Volume Urin (mL)

X $\quad$ : Rata-rata

SD : :Standar Deviasi

Tabel 4. Hasil pengamatan warna urin

\begin{tabular}{cc}
\hline Kelompok & $\begin{array}{c}\text { Warna Urin Mencit } \\
\text { /120 menit setelah perlakuan }\end{array}$ \\
\hline 1 & Kuning \\
\hline 2 & Kuning Muda \\
\hline 3 & Kuning \\
\hline 4 & Kuning Muda \\
\hline 5 & Kuning Pucat \\
\hline
\end{tabular}

Keterangan

Kelompok 1 : Diberikan suspensi Na-CMC 1\% b/v.

Kelompok 2 : Diberikan suspensi furosemid 0,0041\% b/v.

Kelompok 3 : Diberikan ekstrak etanol daun lamtoro $25 \% \mathrm{~b} / \mathrm{v}$.

Kelompok 4 : Diberikan ekstrak etanol daun lamtoro $50 \% \mathrm{~b} / \mathrm{v}$.

Kelompok 5 : Diberikan ekstrak etanol daun lamtoro $75 \%$ b/v.

Hasil pengamatan kejernihan urin menunjukan hasil untuk kejernihan urin pada kelompok 1 sampai 4 berwana jernih sedangkan untuk kelompok 5 berwarna agak keruh. Hasil tersebut menyatakan bahwa untuk kelompok 1 sampai 4 dapat dikatakan urin dalam keadaan normal, sedangkan untuk kelompok 5 urin dalam keadaan tidak normal. Urin dapat dikatakan normal bila berwarna jernih sedangkan urin yang memiliki kekeruhan dapat dikategorikan bahwa urin mulai tidak dalam keadaam normal [5]. Hasil pengamatan kejernihan urin ditampilkan pada tabel 5 
Tabel 5. Hasil pengamatan kejernihan urin

\begin{tabular}{cc}
\hline Kelompok & $\begin{array}{c}\text { Kejernihan Urin } \\
\text { menit setelah perlakuan }\end{array}$ \\
\hline 1 & Jernih \\
\hline 2 & Jernih \\
\hline 3 & Jernih \\
\hline 4 & Jernih \\
\hline 5 & Agak Keruh \\
\hline
\end{tabular}

Keterangan

Kelompok 1 : Diberikan suspensi Na-CMC 1\% b/v.

Kelompok 2 : Diberikan suspensi furosemid 0,0041\% b/v.

Kelompok 3 : Diberikan ekstrak etanol daun lamtoro $25 \% \mathrm{~b} / \mathrm{v}$.

Kelompok 4 : Diberikan ekstrak etanol daun lamtoro 50\% b/v.

Kelompok 5 : Diberikan ekstrak etanol daun lamtoro $75 \%$ b/v

Tabel 6. Hasil pengamatan $\mathrm{pH}$ urin

\begin{tabular}{cc}
\hline Kelompok & $\begin{array}{c}\mathrm{pH} \text { Urin Mencit } \\
\text { menit setelah perlakuan }\end{array}$ \\
\hline 1 & 6 \\
\hline 2 & 6 \\
\hline 3 & 5 \\
\hline 4 & 6 \\
\hline 5 & 6 \\
\hline
\end{tabular}

Keterangan :

Kelompok 1

Kelompok 2

Kelompok 3

Kelompok 4

Kelompok 5

: Diberikan suspensi Na-CMC $1 \% \mathrm{~b} / \mathrm{v}$.

: Diberikan suspensi furosemid 0,0041\% b/v.

: Diberikan ekstrak etanol daun lamtoro $25 \% \mathrm{~b} / \mathrm{v}$

: Diberikan ekstrak etanol daun lamtoro $50 \% \mathrm{~b} / \mathrm{v}$

: Diberikan ekstrak etanol daun lamtoro $75 \% \mathrm{~b} / \mathrm{v}$.

Hasil pengamatan $\mathrm{pH}$ urin menunjukan bahwa untuk masing-masing kelompok setelah perlakuan memiliki derajat keasaman $(\mathrm{pH})$ yang besifat asam. Pengamatan $\mathrm{pH}$ urin bisa dilihat pada tabel 6 . Untuk kelompok 1 bersifat asam yaitu 6 , kelompok 2 bersifat asam yaitu 6, kelompok 3 bersifat asam yaitu 5, kelompok 4 bersifat asam yaitu 6, sedangkan untuk kelompok 5 juga bersifat asam yaitu 6 . Hal ini didukung oleh pernyataan, urin normal umumnya bersifat asam dengan $\mathrm{pH}$ sekitar 6 [5]. Pengaruh perbedaan $\mathrm{pH}$ juga dipengaruhi oleh fisiologi dari hewan uji dimana pabila konsentrasi $\mathrm{H}^{+}$berubah dari normal, maka ginjal akan mengekskresikan urin yang asam/ basa, dengan demikian juga dapat membantu menyesuaikan konsentrasi ion $\mathrm{H}^{+}$cairan tubuh kembali normal [6].

Tabel 7 Indeks aktivitas diuretik mencit setelah perlakuan

\begin{tabular}{|c|c|c|c|c|c|c|c|c|c|c|}
\hline \multirow{2}{*}{ Kelompok } & \multicolumn{8}{|c|}{ Volume Urin $(\mathrm{mL})$} & \multirow{2}{*}{$\begin{array}{c}\Sigma \\
(\mathrm{mL})\end{array}$} & \multirow[t]{2}{*}{ IAD } \\
\hline & 15 & 30 & 45 & 60 & 75 & 90 & 105 & 120 & & \\
\hline 1 & 0.1 & 0.4 & 0.1 & 0.3 & 0.1 & 0.0 & 0.0 & 0.0 & 1 & - \\
\hline 2 & 0.6 & 0.7 & 1.0 & 1.2 & 1.2 & 1.0 & 0.8 & 0.5 & 7 & 7.0 \\
\hline 3 & 0.1 & 0.0 & 0.5 & 0.7 & 0.5 & 0.2 & 0.0 & 0.0 & 2 & 2.0 \\
\hline 4 & 0.4 & 0.6 & 1.0 & 1.0 & 1.0 & 0.7 & 0.5 & 0.2 & 5.4 & 5.4 \\
\hline 5 & 0.6 & 0.8 & 1.2 & 1.3 & 1.1 & 0.8 & 0.6 & 0.1 & 6.5 & 6.5 \\
\hline
\end{tabular}


Keterangan :

Kelompok 1

Kelompok 2

Kelompok 3

Kelompok 4

Kelompok 5

$\Sigma$

IAD

: Diberikan suspensi Na-CMC 1\% b/v.

: Diberikan suspensi furosemid 0,0041\% b/v.

: Diberikan ekstrak etanol daun lamtoro $25 \% \mathrm{~b} / \mathrm{v}$.

: Diberikan ekstrak etanol daun lamtoro $50 \%$ b/v.

: Diberikan ekstrak etanol daun lamtoro $75 \% \mathrm{~b} / \mathrm{v}$.

: Jumlah Volume Urin

: Indeks Aktivitas Diuretik Mencit

Hasil pengamatan indkes aktivitas diuretik menunjukan hasil 2 jam setelah perlakuan kelompok mencit yang diberikan variasi ekstrak dan kelompok furosemid memiliki penaikan volume urin dari kelompok negatif (Na-CMC). Sementara itu untuk indeks aktivitas diuretik masing-masing kelompok juga menunjukan perbedaan. Aktivitas diuretik dapat dikatakan kuat jika nilai yang diperoleh dari perhitungan IAD (indeks aktivitas diuretik) lebih dari 1.525 yang dinyatakan dalam bentuk hasil perhitungan tersebut [1]. Hasil pengamatan indkes aktivitas diuretik bisa dilihat pada tabel 7

Volume akumulasi urin yang didapatkan pada masing-masing kelompok kemudian dilanjutkan dengan menghitung indeks aktivitas diuretik (IAD) berdasarkan persamaan antara volume urin kelompok uji dibandingkan dengan kelompok negatif. Data tersebut tergambar pada grafik yang ditampilkan pada gambar 1 . Hasil didapatkan bahwa pada kontrol negatif ( $\mathrm{Na} \mathrm{CMC}$ ) memiliki volume urin yang rendah dibandingkan kontrol positif (Furosemid) dan kelompok 3, 4, dan 5. Hal ini disebabkan karena kontrol negatif tidak terkandung zat aktif yang dapat meningkatkan volume urin sehingga menyebabkan ekskresi urin yang keluar sedikit. Diketahui bahwa daun lamtoro (Leucaena leucocephala L.) mengandung zat aktif berupa alkaloid, saponin, flavonoid, mimosin, lektin, protein, lemak, kalsium, fosfor, zat besi, vitamin A dan vitamin B.

Senyawa flavonoid diduga memiliki efek diuretik untuk meningkatkan volume urin. Namun perlu juga diperhatikan untuk penggunaan ekstrak daun lamtoro yang memiliki sifat sebagai diuretik dengan adanya senyawa seperti flavonoid dan alkaloid, karena dapat memberikan efek samping seperti hypokalemia $[7,9,13]$.

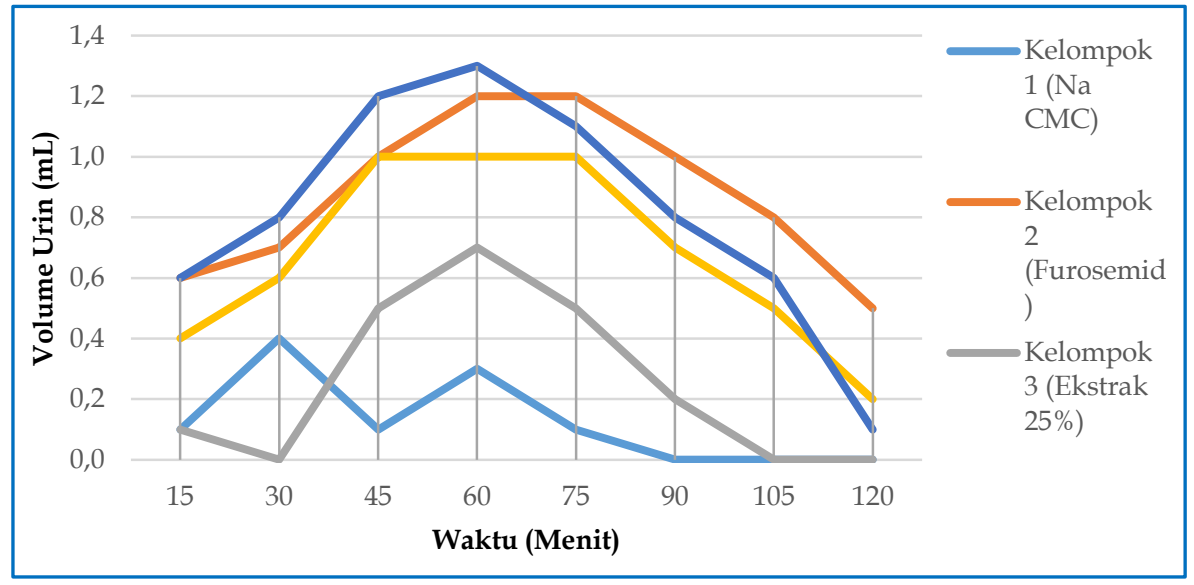

Gambar 3.1 Grafik peningkatan akumulasi volume urin mencit

Untuk mengetahui perbedaan yang bermakna dari masing-masing kelompok uji. Antara kelompok 1 yang diberikan suspensi Na-CMC 1\% b/v, kelompok 2 diberikan suspensi furosemide $0,0041 \% \mathrm{~b} / \mathrm{v}$, kelompok 3 diberikan ekstrak daun lamtoro $25 \% \mathrm{~b} / \mathrm{v}$, 
kelompok 4 diberikan ekstrak daun lamtoro $50 \%$ b/v, dan kelompok 5 yang juga diberikan ekstrak daun lamtoro 75\%. Analisis yang digunakan adalah ANOVA (Analysis Of Variances) One Way pada a $=0,01$, dengan taraf kepercayaan $99 \%$. Semakin kecil peluang terjadinya kesalahan seperti $\alpha=0,01$, maka kepercayaan kita terhadap suatu hasil yang didapat akan semakin besar [3]. Berdasarkan analisis yang telah dilakukan, didapatkan bahwa terdapat pengaruh antara masing-masing kelompok uji dengan nilai $p<0.01(\alpha=0,01)$. Hal ini menunjukan bahwa setiap kelompok perlakuan memberikan peningkatan terhadap volume urin yang dihasilkan.

Selanjutnya dilakukan juga uji Post Hoc Tests untuk mengetahui perbedaan antara masing-masing kelompok perlakuan. Berdasarkan pengolahan data, hasil menunjukan untuk kelompok 1 pemberian suspensi Na-CMC 1\% tidak memberikan pengaruh yang bermakna terhadap peningkatan volume urin. Hal ini berbeda dengan kelompok 2, 3, 4, dan 5 dari analisis ini menunjukan adanya peningkatan volume urin dari variasi konsentrasi dosis ekstrak daun lamtoro yang diberikan pada masing-masing hewan uji. Maka dari analisis yang telah dilakukan ekstrak daun lamtoro (Leucaena leucocephala L.) mempunyai efek diuretik pada mencit jantan.

\section{Kesimpulan}

Kesimpulan yang dapat ditarik dari penelitian ini yaitu ekstrak etanol daun lamtoro (Leucaena leucocephala L.) memiliki aktivitas diuretik pada mencit jantan (Mus musculus) yang diamati dari peningkatan volume urin dihasilkan selama 120 menit setelah perlakuan dan juga berdasarkan peningkatan volume urin yang memiliki aktivitas diuretik paling optimal adalah konsentrasi $75 \%$ dengan volume urin sebanyak $6.5 \mathrm{~mL}$ dalam 120 menit.

Referensi

[1]. Adriyanto, Poniman, dkk. 2013. Evaluasi Aktivitas Diuretik Ekstrak Etanol Buah Belimbing Wuluh (Averrhoa bilimbi) sebagai Diuretik Alami: Kadar Natrium, Kalium, Dan pH Urin. Bogor: Institut Pertanian Bogor.

[2]. Anna. 2011. Uji Efek Diuretik Ekstrak Etanol 70\% Daun Ceplukan (Physalis angulate L.). Surakarta: Universitas Muhammadiyah

[3]. Azwar. Saifuddin. 2005. Signifikan Atau Sangat Signifikan. Buletin Psikologi. Yogyakarta: Universitas Gadjah Mada

[4]. Dalimartha, S. 2008. 1001 Resep Herbal. Jakarta: Penebar Swadaya.

[5]. Gandasoebrata. 1992. Penuntun Laboratorium Klinik. Jakarta: PT. Dian Rakyat.

[6] Guyton, A. C. 1997. Fisiologi Manusia dan Mekanisme Penyakit III (diterjemahkan oleh P. Andrianto). Jakarta: EGC

[7] Iriany, R. dkk. 2014. Uji Efektivitas Ekstrak Etanol Kulit Buah Labu Siam (Sechiumedule Jacq. S.) Sebagai Diuretik Pada Tikus Jantan Galur Wistar (Rattusnovergicus sp.) Jurnal Ilmiah Farmasi Vol (3) No. 2: 67-27

[8]. Katzung, B. G. 2001. Farmakologi Dasar dan Klinik, 433-444, Diterjemahkan oleh Bagian Farmakologi Fakultas Kedokteran Universitas Airlangga. Jakarta: Salemba Medika. 
[9]. Motong, Agustina Sesilia Ose. 2017. UJI EFEK DIURETIK EKSTRAK ETANOL DAUN SELEDRI (Apium graveolens L.) pada TIKUS PUTIH JANTAN GALUR WISTAR. Diss. Surakarta: Universitas Setia Budi.

[10]. Nafraldi, Gunawan dan Gam Sulistia. 2007. Farmakologi dan Terapi edisi 5 cetakan ulang dengan tambahan. Jakarta: Universitas Indonesia press.

[11]. Permadi, A. 2006. Tanaman Obat Pelancar Air Seni. Jakarta: Penebar Surabaya

[12]. Putri, Zulia Ika. 2017. Efek Diuretik Ekstrak Metanol Daun Salam (Eugenia polyantha) Pada Kelinci Jantan (Oryctolagus cuniculus). Gorontalo: Universitas Negeri Gorontalo

[13] Praja, Rasmi Zakiah Oktarlina. 2016. Uji Efektivitas Daun Petai Cina (Leucaena glauca) sebagai antiinflamasi dalam pengobatan luka bengkak. Lampung: Universitas Lampung

[14]. Sunaryo. 1995. Diuretik dan Antidiuretik. Farmakologi dan Terapi. Jakarta: Gaya Baru

[15]. Tahono. 1999. Pengantar Analisa Laboratorium Patologi Klinik II. Surakarta: Fakultas Kedokteran UNS

[16]. Jones, W.P. dan Kinghorn, A.D., 2006, Extraction of plant secondary metabolites, In:L Sarker, S.D., Latif, Z. dan Gray, A.I,. Natural Products Isolation, $2^{\text {nd }}$ Ed. New Jersey Humana Press.

[17]. Robinson, T., 1995, Kandungan Senyawa Oraganik Tumbuhan Tinggi., ITB. Bandung.

[18]. Prashant, 2011, Phytochemical Screening and Extraction, Internationale Pharmaceutica Sciencia, 1(1):1-9. 